\title{
Isolation of a benomyl-resistant allele of the $\beta$-tubulin gene from Septoria nodorum and its use as a dominant selectable marker
}

\author{
R. Neil Cooley, ${ }^{1 *}$ Robert F. M. van Gorcom, ${ }^{2}$ Cees A. M. J. J. van den Hondel ${ }^{2}$ and \\ CHRISTOPHER E. CATEN ${ }^{1}$ \\ ${ }^{1}$ School of Biological Sciences, University of Birmingham, PO Box 363, Birmingham B15 2TT, UK \\ ${ }^{2}$ Medical Biological Laboratory TNO, PO Box 45, 2280 AA Rijswijk, The Netherlands
}

(Received 13 December 1990; revised 30 April 1991; accepted 10 June 1991)

\begin{abstract}
We have developed a homologous transformation system for the wheat-pathogenic fungus Septoria nodorum based on a benomyl-(MBC-) resistant allele of the $\beta$-tubulin gene. The $\beta$-tubulin gene was isolated by heterologous hybridization from a cosmid library prepared from an MBC-resistant mutant. Cosmids carrying the gene conferred $\mathrm{MBC}$ resistance when introduced into a sensitive strain, demonstrating that resistance to $\mathrm{MBC}$ fungicides in $S$. nodorum may be determined by the $\beta$-tubulin gene. This MBC resistant allele of the $\beta$-tubulin gene $\left(t u b A^{R}\right)$ was subcioned into pUC18 and used as a dominant selectable marker for transformation of wild-type sensitive strains. Transformants arose at frequencies of approximately 5 per $\mu \mathrm{g}$ of DNA, were integrative in nature and were mitotically stable. Some transformants showed a marked reduction in vigour, both in the presence and absence of $\mathrm{MBC}$; this is thought to arise from overproduction of $\beta$-tubulin. The $S$. nodorum tub $^{\mathrm{R}}$ gene also conferred $\mathrm{MBC}$ resistance on the related species Leptosphaeria maculans, a pathogen of Brassica, following its introduction by cotransformation. Probing digested $S$. nodorum DNA with tub $\mathrm{A}^{\mathrm{R}}$ at low stringency revealed only a single $\beta$-tubulin gene. We anticipate that $t u b \mathrm{~A}^{\mathrm{R}}$ will prove a useful tool for the investigation of the pathogenicity of $S$. nodorum and other fungi.
\end{abstract}

\section{Introduction}

Recombinant DNA technology is increasingly being used to investigate the mechanisms of fungal pathogenesis to plants (Yoder et al., 1986; Leong \& Holden, 1989). We are attempting to clone by complementation genes involved in pathogenesis from Septoria nodorum (teleomorph Leptosphaeria nodorum), which is a major pathogen of wheat (King et al., 1983). This approach requires a gene transfer system for analysis of the phenotypic effects of cloned sequences following their reintroduction into $S$. nodorum cells. We succeeded in transforming $S$. nodorum with a vector, pAN7-1, which carries the Escherichia coli hygromycin B phosphotransferase gene under the control of expression sequences from Aspergillus nidulans (Cooley et al., 1988). However, the frequency of transformation with this vector, 5-25 transformants per $\mu \mathrm{g}$ DNA, is too low to permit screening of a gene library by complementation. To

Abbreviations: MBC, methyl benzimidazole-2-yl carbamate (carbendazim), the active ingredient of benomyl; $\mathrm{HmB}$, hygromycin $\mathrm{B}$; superscript $\mathbf{R}$, resistant. determine whether the use of a selectable marker originating from $S$. nodorum would increase the efficiency of transformation in this species, we undertook to develop a homologous transformation system to replace the heterologous system based on the $E$. coli hygromycin $B$ resistance gene.

With genetically undeveloped fungi, such as $S$. nodorum, it is often necessary to transform wild-type recipients and hence any system must be based on a dominant selectable gene. Antibiotic resistance genes have frequently been used in this way (Yoder et al., 1986; Punt et al., 1987; Rambosek \& Leach, 1987) but their bacterial origin excluded them from our purpose. Fungicide resistance is an obvious analogy that could be exploited in a homologous system. However, the molecular basis of the resistance to many fungicides is poorly understood and candidate selectable genes cannot be readily identified and cloned. An exception is resistance to the benzimidazole (MBC) group of fungicides which in $A$. nidulans, Neurospora crassa and Saccharomyces cerevisiae arises through mutations in the $\beta$-tubulin gene (Sheir-Neiss et al., 1978; Orbach et al., 1986; Thomas et al., 1985). A cloned benomyl-resistance gene from $N$. 
crassa (tub-2) has been used in a highly efficient homologous transformation system for that species (Orbach et al., 1986; Vollmer \& Yanofsky, 1986). Wildtype $S$. nodorum is sensitive to $\mathrm{MBC}$ fungicides and can be transformed to resistance by the Neurospora tub-2 gene (Cooley et al., 1990), suggesting that MBC resistance might form the basis of a homologous transformation system. Mutants resistant to MBC can be readily isolated in $S$. nodorum (Horsten \& Fehrmann, 1980) but the mechanism of resistance in this species has not been established. On the assumption that resistance arises through modification of the $\beta$-tubulin, we set out to clone the $\beta$-tubulin gene from an MBC-resistant mutant of $S$. nodorum and to use it as a dominant selectable marker for transformation of this species and other phytopathogenic fungi.

\section{Methods}

Strains and vectors. The wheat-adapted strain of Septoria nodorum BS171 (Osbourn et al., 1986) was used as the wild-type throughout. The Leptosphaeria maculans strain used (345A4) was obtained from Dr K. J. Doughty (Institute of Arable Crops Research-Rothamsted Experimental Station, UK). Escherichia coli strain DH1 was used as the host for all plasmids, except pUC18 derivatives containing subcloned $S$. nodorum DNA fragments, where JM83 was used. Strain JA221 was used as the recipient in transfections of the cosmid library.

The plasmid pAN7-1 was constructed by Punt et al. (1987) and contains the $E$. coli hygromycin B $(\mathrm{HmB})$ resistance gene under the control of Aspergillus nidulans expression sequences. Cosmid pAN7-2 is a derivative of pAN7-I (P. J. Punt, personal communication) containing a unique $B g / \mathrm{II}$ site and a $\lambda$-cos site. Plasmid $\mathrm{pB} 5$ was used as the source of the $A$. nidulans $\beta$-tubulin gene benA (May et al., 1985).

Media and culture conditions. Standard methods for the storage, growth and sporulation of $S$. nodorum and the composition of minimal medium (MM) and sporulation medium $(\mathrm{CzV} 8 \mathrm{CS})$ are described elsewhere (Newton \& Caten, 1988). The medium used in $S$. nodorum transformations is described by Cooley et al. (1988). Oxoid potato dextrose agar (PDA) was used as the basal medium for growth of $L$. maculans and spores were produced by growing colonies on $\mathrm{CzV} 8 \mathrm{CS}$ medium under the same conditions as used for sporulation of $S$. nodorum. L. maculans was also grown in $\mathrm{CzV} 8 \mathrm{CS}$ medium. MBC was added to media as carbendazim from a $1 \mathrm{mg} \mathrm{ml}^{-1}$ stock solution in methanol.

Isolation of $M B C$-resistant mutants. $\mathrm{MBC}$-resistant $\left(\mathrm{MBC}^{\mathrm{R}}\right)$ mutants of $S$. nodorum were isolated by overlaying BS171 spore suspensions, which had been UV-irradiated to give a survival rate of 3-10\%, on MM plates containing $2.0 \mu \mathrm{g} \mathrm{MBC} \mathrm{ml}^{-1}$. Approximately $2 \times 10^{6}$ viable spores were inoculated on to each plate and these were incubated at $25^{\circ} \mathrm{C}$ in the dark

Pathogenicity assays. Pathogenicity was tested in detached wheat leaf assays as described by Cooley et al. (1988). To test MBC resistance during growth on plant tissue, the detached wheat leaves were placed on water-agar containing benlate (Du Pont) at a range of concentrations up to $40 \mu \mathrm{g} \mathrm{ml}^{-1}$. Benlate contains $50 \%$ active ingredient of $\mathrm{MBC}$.

Preparation and transformation of protoplasts. Protoplasts of $S$. nodorum and L. maculans were prepared and transformed as described by Cooley et al. (1988). L. maculans protoplasts were regenerated on PDA medium buffered with $1 \mathrm{M}$-sucrose. Direct selection for MBC resistance was applied by overlaying protoplasts on to plates containing $\mathrm{MBC}$ at a final concentration of $2.5 \mu \mathrm{g} \mathrm{ml}^{-1}$.

DNA isolation and molecular analyses. DNA was isolated from $S$ nodorum as described by Cooley et al. (1988). ${ }^{32}$ P-labelled DNA probes were produced by hexanucleotide random primer labelling (Feinberg \& Vogelstein, 1983, 1984). All other DNA manipulations, including restriction digests, ligations, in vitro packaging, colony hybridization and Southern blotting, were as described by Maniatis et al. (1982) or in accordance with the manufacturers" recommendations.

Construction of an $S$. nodorum genomic library and isolation of $\beta$ tubulin-specific cosmid clones. High-molecular-mass DNA from $\mathrm{MBC}^{\mathrm{R}}$ mutant BSm300 was partially digested with Sau3A and sizefractionated on salt gradients $(1.25-5 \mathrm{M}-\mathrm{NaCl})$ in order to recover fragments approximately $30 \mathrm{~kb}$ in size. These were ligated into $B g / \mathrm{II}-$ linearized pAN7-2 pre-treated with alkaline phosphatase : $0 \cdot 1 \mu \mathrm{g}$ insert DNA was ligated with $0.4 \mu \mathrm{g}$ vector DNA in the presence of $20 \mathrm{~mm}$ Tris/ $\mathrm{HCl}, \mathrm{pH} 7 \cdot 6,10 \mathrm{~mm}-\mathrm{MgCl}_{2}, 1 \mathrm{~mm}-\mathrm{ATP}, 1 \mathrm{~mm}-\mathrm{DTT}$, and 0.1 unit of T4 DNA ligase in a final volume of $15 \mu \mathrm{l}$ for $2 \mathrm{~h}$ at room temperature. The products were packaged, transfected into $E$. coli JA22l and the library plated on to nitrocellulose filters overlaying L-agar containing $150 \mu \mathrm{g}$ ampicillin $\mathrm{ml}^{-1}$. Replica filters, each containing approximately 3000 colonies, were hybridized to ${ }^{32} \mathrm{P}$-labelled $5.4 \mathrm{~kb}$ Pst I fragment of pB5, containing the $A$. nidulans benA gene (May et al., 1985). Hybridization was carried out under conditions of medium stringency at $42{ }^{\circ} \mathrm{C}$ in a buffer containing $37.5 \%(\mathrm{v} / \mathrm{v})$ formamide, $5 \times \mathrm{SSC}$, $1 \times$ Denhardt's solution, $100 \mu \mathrm{g}$ salmon sperm DNA ml $\mathrm{m}^{-1}, 10 \%(\mathrm{w} / \mathrm{v})$ dextran sulphate, $20 \mathrm{~mm}$-orthophosphate, $\mathrm{pH} 6 \cdot 5$.

\section{Results and Discussion}

\section{Isolation of $M B C^{R}$ mutants of $S$. nodorum}

Following incubation of the $\mathrm{MBC}^{\mathrm{R}}$ mutant selection plates, strongly growing colonies developed amongst a weak background growth at a rate of $5 \times 10^{-6}$. After hyphal transfer on to fresh plates approximately onethird of these initially selected colonies were able to grow at $20 \mu \mathrm{g} \mathrm{MBC} \mathrm{ml}{ }^{-1}$, which is ten times the concentration needed to completely inhibit growth of $S$. nodorum BS171. Similar levels of resistance occur in benomylresistant mutants of $N$. crassa (Borck \& Braymer, 1974) and $A$. nidulans (van Tuyl, 1977).

Six of these $M B C^{R}$ mutants were tested for pathogenicity in detached wheat leaf assays in the presence and absence of benlate. Without benlate all six mutants produced lesions at least the size of those produced by BS171. Furthermore, all six also produced sizeable lesions on leaves placed on water-agar containing $20 \mu \mathrm{g}$ benlate $\mathrm{ml}^{-1}$, whilst BS171 gave a much reduced lesion under these conditions. One mutant, BSm300, still produced large lesions on water-agar containing $40 \mu \mathrm{g}$ benlate $\mathrm{ml}^{-1}$. Thus, these mutants express MBC resistance both in vivo and in planta and show no loss of pathogenicity. 
Isolation and characterization of $\beta$-tubulin-specific cosmid clones

Thirteen cosmid clones from the BSm300 genomic library produced positive signals on five pairs of duplicate filters when probed with the $A$. nidulans ben $\mathrm{A}$ gene. These were picked and purified, and cosmid DNA from each of these $\beta$-tubulin-specific clones was isolated, digested with BamHI and probed with the $A$. nidulans ben A gene in Southern hybridizations. Ten of these 13 clones produced positive signals corresponding to fragments of 3.0 and $4.1 \mathrm{~kb}$, suggesting that the region which contains homology to the benA probe possesses an internal BamHI site (data not shown). The other three clones each gave single positive signals, corresponding to fragments of $3 \cdot 0,4 \cdot 1$ and $5 \cdot 5 \mathrm{~kb}$, and probably represent incomplete clones of the $\beta$-tubulin-specific region cloned in the other 10 clones. These results suggest that $S$. nodorum has a single $\beta$-tubulin gene, or at least only one gene with enough homology to the $A$. nidulans benA gene to allow its isolation under the conditions used.

Ten of the $\beta$-tubulin-specific cosmid clones, including the three presumed incomplete clones, were transformed into $S$. nodorum BS171 by selecting for hygromycin resistance. $\mathrm{HmB}^{\mathrm{R}}$ transformants arose at relatively low frequencies, between 0.4 and 1.2 per $\mu$ g DNA, compared to the frequency obtained using pAN7-1 (5-25 per $\mu \mathrm{g}$ DNA; Cooley et al., 1988). These $\mathrm{HmB}^{\mathrm{R}}$ transformants were transferred to $\mathrm{MM}$ plates containing $\mathrm{HmB}$ or MBC. As expected, all grew on plates containing enough $\mathrm{HmB}$ to completely inhibit growth of BS171 (150 $\mu \mathrm{g}$ $\mathrm{HmB} \mathrm{ml}{ }^{-1}$ ). Furthermore, transformants from seven of the 10 cosmid clones tested grew on plates containing $2.5 \mu \mathrm{g} \mathrm{MBC} \mathrm{ml}^{-1}$, whilst BS171 and transformants of the other three clones were completely inhibited at this concentration. The seven cosmid clones that conferred $\mathrm{MBC}$ resistance all contained benA-specific 3.0 and $4 \cdot 1 \mathrm{~kb}$ Bam HI fragments, whilst the three that did not lacked one or more of these fragments. These results demonstrate that in $S$. nodorum, as in a number of other fungi, resistance to benzimidazole fungicides may be determined by the $\beta$-tubulin gene (Sheir-Neiss et al., 1978; Orbach et al., 1986; Thomas et al., 1985; Hiraoka et al., 1984). That the three cosmid clones which gave single positive hybridization signals were unable to confer MBC resistance is consistent with the idea that these are incomplete clones of the same gene contained in the other 10 clones.

The level of MBC resistance of the cosmid clone transformants was intermediate between that of the wild-type recipient (BS171) and the $\mathrm{MBC}^{\mathrm{R}}$ mutant (BSm300) from which the $\beta$-tubulin gene was obtained. Similar results have been seen in benomyl-resistant transformants of $A$. nidulans and $N$. crassa, where

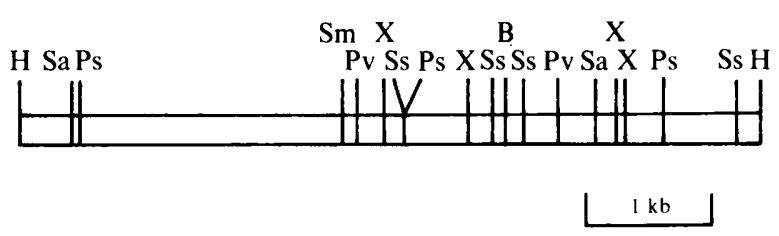

Fig. 1. Restriction map of the $5.8 \mathrm{~kb}$ HindIII fragment contained in pTUBA4. B, BamHI; H, HindIII; Ps, PstI ; Pv, PvuII; Sa, SalI; Sm, SmaI; Ss, SstI; X, XhoI.

resistant alleles of the ben $\mathrm{A}$ and $t u b-2$ genes were used, respectively (G. S. May \& M. J. Orbach, personal communications). It is likely that the transformed resistant allele shows incomplete dominance with respect to the sensitive recipient allele, so that both resistant and sensitive $\beta$-tubulin polypeptides are produced and incorporated into the microtubules of transformants, producing intermediate levels of resistance.

\section{Subcloning the $S$. nodorum $\beta$-tubulin gene and its use as a} dominant selectable marker

The $S$. nodorum $\beta$-tubulin gene was subcloned into pUC18 as a $5.8 \mathrm{~kb}$ HindIII fragment (Fig. 1) to produce plasmid pTUBA4. This plasmid was tested for its ability to transform BS171, selecting directly for MBC resistance. After $14 \mathrm{~d}$ incubation at $25^{\circ} \mathrm{C}$, strongly growing $\mathrm{MBC}^{\mathrm{R}}$ colonies appeared at frequencies of 3-6 per $\mu \mathrm{g}$ pTUBA4 DNA, but were absent from minus-DNA control plates (Fig. 2a). After transfer on to fresh plates all putative transformants tested grew at $2.5 \mu \mathrm{g} \mathrm{MBC}$ $\mathrm{ml}^{-1}$ whilst BS171 was completely inhibited at this concentration (Fig. 2b). These putative transformants varied in growth vigour on $\mathrm{MBC}$-containing media, suggesting different levels of $\mathrm{MBC}$ resistance. However, some showed reduced growth and abnormal colony morphology in the absence of $\mathrm{MBC}$, making the relative resistance levels difficult to assess. The reduced growth in the absence of fungicide is likely to be due to the inhibitory effects of overproduction of $\beta$-tubulin similar to the overexpression of either ben $\mathrm{A}$ or tubC in $A$. nidulans (Waring et al., 1989). The heterogeneity of phenotype in the absence of $\mathrm{MBC}$ was not apparent amongst the cosmid clone transformants.

In addition to the large $\mathrm{MBC}^{\mathrm{R}}$ colonies, small colonies developed on both the pTUBA4 transformation plates and the minus-DNA control plates. They appeared at a higher frequency on the transformation plates (Fig. $2 a$ ). The small colonies on the minus-DNA control plates may have been due to leaky background growth, perhaps from particularly large protoplast aggregates. Those on the transformation plates were probably a mixture of the above plus abortive transformants, similar to those 

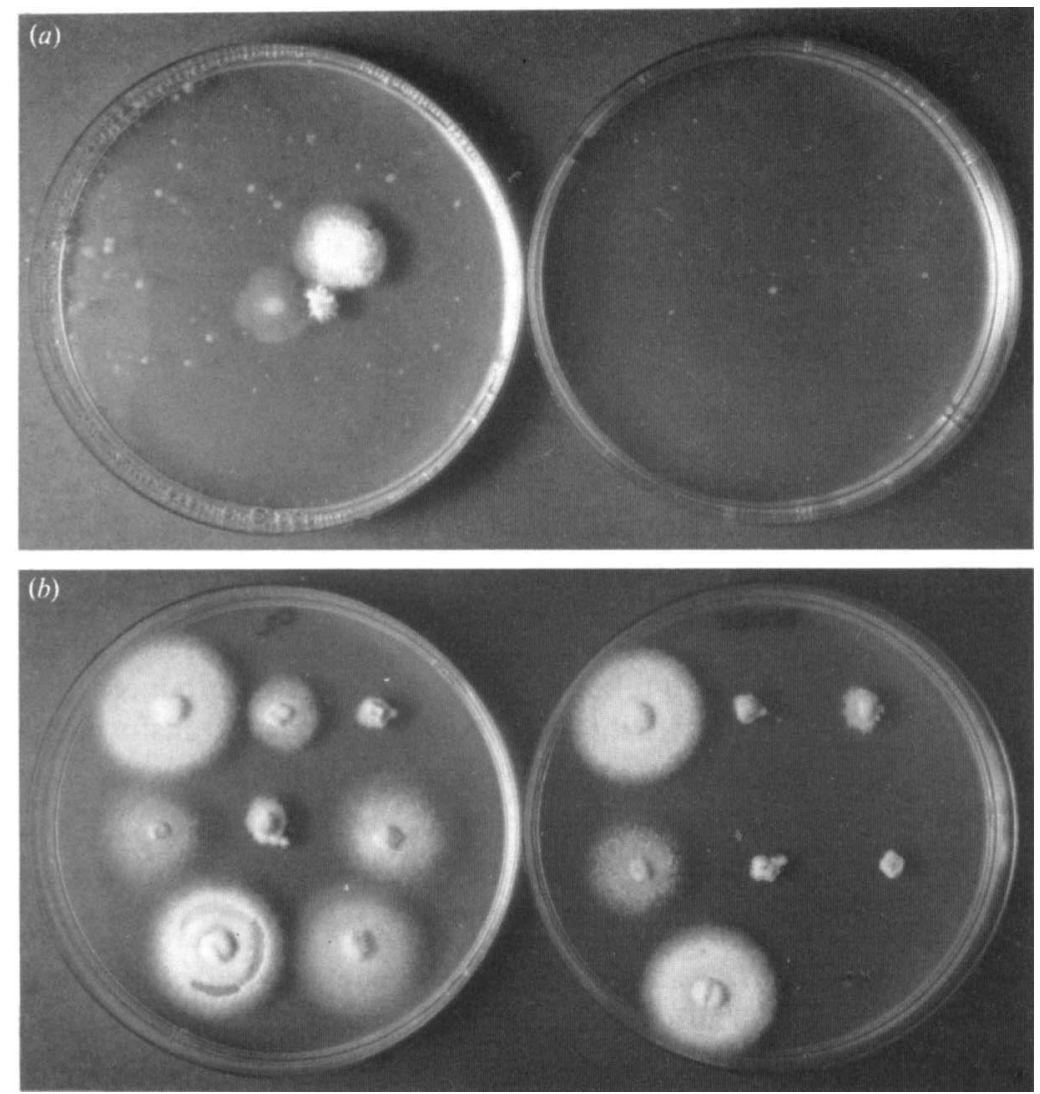

Fig. 2. The selection $(a)$ and retesting $(b)$ of pTUBA4 transformants. (a) Aliquots of BS171 protoplasts were treated with pTUBA4 (left) or used as minusDNA controls (right) and plated on buffered MM

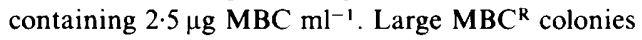
arose only on plates inoculated with DNA-treated protoplasts. (b) Six putative pTUBA4 transformants and strains BS171 and BSm300 (lower right and left inocula on each plate, respectively) were retested on MM (left) and MM containing $2.5 \mu \mathrm{g} \mathrm{MBC} \mathrm{ml}^{-1}$ (right). All six putative transformants grew on $\mathrm{MBC}$, despite some also showing altered growth in its absence. observed when using pAN7-1 to produce $\mathrm{HmB}^{\mathrm{R}}$ transformants (Cooley et al., 1988). None of these small colonies from either pTUBA4-treated or minus-DNA plates were able to grow following hyphal transfer to

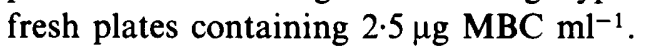

\section{Molecular analysis of putative $M B C^{R}$ transformants}

DNA from two $\mathrm{HmB}^{\mathrm{R}}$ colonies, from each of three cosmid clones which conferred $\mathrm{MBC}$ resistance, was probed with ${ }^{32} \mathrm{P}$-labelled whole pAN7-2 DNA in Southern hybridizations. All six $\mathrm{HmB}^{\mathrm{R}} / \mathrm{MBC}^{\mathrm{R}}$ strains gave positive hybridization signals, confirming that they had been transformed with the pAN7-2 cosmid clones (data not shown). DNA from BS171 gave no such signal.

DNA from BS171 and three putative $\mathrm{MBC}^{\mathrm{R}}$ pTUBA4 transformants (T1, T2, T3) was probed with ${ }^{32} \mathrm{P}$-labelled pUC18 DNA in Southern hybridizations (Fig. 3). Uncut DNA gave a single high-molecular-mass positive signal, which was absent from the BS171 track. This both confirms that these are pTUBA4 transformants and demonstrates the integrative nature of transformation.

DNA digested with $X b a I$, an enzyme with a unique site in pTUBA4, gave different patterns of hybridization

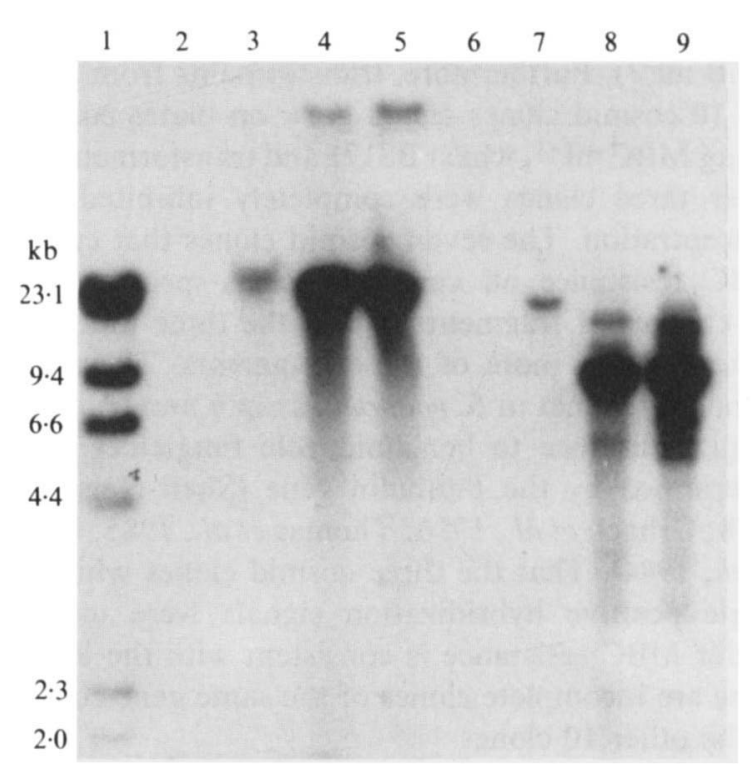

Fig. 3. Southern hybridization analysis of pTUBA4 transformants. DNA from strain BS171 (lanes 2 and 6) and three pTUBA4 transformants (T1, lanes 3 and 7; T2, lanes 4 and $8 ; \mathrm{T} 3$, lanes 5 and 9) was probed with ${ }^{32}$ P-labelled pUC18. DNA in lanes $2-5$ was undigested, whilst that in lanes 6-9 was digested with $X b a$ I. Lane 1 contained $\lambda$-HindIII size standards. Lanes 2-9 were each loaded with $0 \cdot 2 \mu \mathrm{g}$ of DNA. 
between transformants. T2 and T3 (Fig. 3, lanes 8 and 9) produced major positive signals corresponding to a fragment the same size as linearized pTUBA4 $(8.4 \mathrm{~kb})$, a pattern indicative of multiple integration events at one or more sites. A number of less intense signals were also seen in these two lanes, representing the border regions of these multiple integration events and/or the products of single integration events. The large number of these bands indicates that integration had taken place at a number of sites. Thus, integration does not only take place through homologous recombination at the site of the endogenous wild-type tubA allele. T1 (Fig. 3, lane 7) gave only a single hybridization signal. Single integration events normally produce two such signals. However, the pattern observed would be consistent with this type of event if the site of integration on the vector were close to the $X b a I$ site, producing a fragment bearing little or no homology to the pUC 18 probe. These integration events are similar to those seen when selecting for the $\mathrm{HmB}$ resistance carried by pAN7-1, except that no single integration events have been detected in the latter (Cooley et al., 1988).

The results in Fig. 3 demonstrate that different transformants vary in the number of copies of pTUBA4 integrated. The reduced growth rate in the absence of $\mathrm{MBC}$ and the levels of MBC resistance shown by pTUBA4 transformants did not correlate simply with variation in copy number. For example, two of the three transformants shown in Fig. 3, T1 and T2, had similar phenotypes, with reduced growth in the absence of MBC but no further inhibition in its presence, despite having different copy numbers of integrated pTUBA4. Also, T3 was uninhibited in either the presence or absence of MBC despite having approximately the same copy number of integrated pTUBA4 as T2. Overproduction of $\beta$-tubulin may be responsible for the inhibition of growth in the absence of fungicide in $\mathrm{T} 1$ and $\mathrm{T} 2$; however, this does not simply result from an increased copy number of the $\beta$-tubulin gene in these transformants.

\section{Mitotic stability of $M B C^{R}$ transformants}

The stability of primary transformants was tested to determine whether or not they arose as heterokaryons. An origin in this way is possible since PEG 4000 stimulates protoplast fusion. We found segregation of the $\mathrm{MBC}^{\mathrm{R}}$ phenotype amongst single-spore progenies derived from individual primary transformant colonies in four out of nine cosmid clone transformants and two out of six pTUBA4 transformants. This single-spore analysis was repeated for one resistant single-spore colony from each original transformant. This time no segregation was seen. These results are similar to those obtained with pAN7-1 transformants (Cooley et al., 1988) and indicate

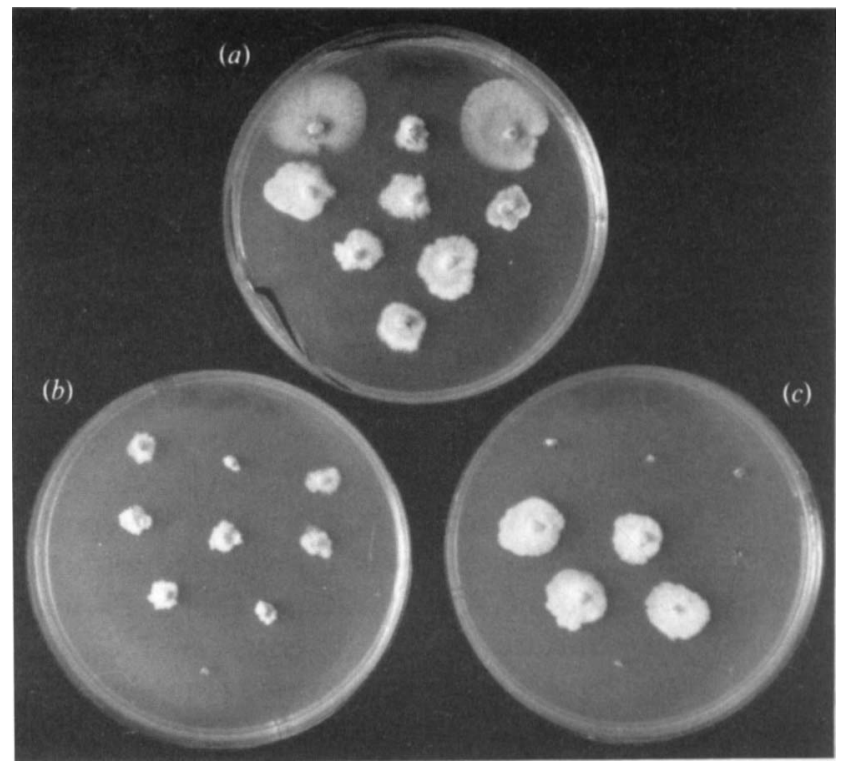

Fig. 4. Transformation of $L$. maculans to $\mathrm{MBC}$ resistance. L. maculans strain 345A4 was used in pAN7-1 transformation and pAN71/pTUBA4 cotransformation experiments. Three $\mathrm{HmB}^{\mathrm{R}}$ pAN7-1 transformants (top row), strain 345A4 (bottom row) and five $\mathrm{HmB}^{\mathrm{R}}$ transformants from a pAN7-1/pTUBA4 cotransformation experiment (middle rows) were each plated on three types of media: (a) PDA, $(b)$ PDA containing $150 \mu \mathrm{g} \mathrm{HmB} \mathrm{ml} \mathrm{H}^{-1}$ and (c) PDA containing $2.5 \mu \mathrm{g}$ $\mathrm{MBC} \mathrm{ml} \mathrm{l}^{-1}$. Four out of the five $\mathrm{HmB}^{\mathrm{R}}$ transformants from the $\mathrm{pAN7}$ 1/pTUBA4 experiment had been cotransformed to $M B C$ resistance.

that, although primary transformant colonies may be heterokaryons, purified $\mathrm{MBC}^{\mathrm{R}}$ transformants are stable through mitotic divisions.

\section{Transformation of a heterologous species to $M B C$ resistance}

Plasmid pTUBA4 was transferred into $L$. maculans strain 345 A4 by cotransformation with pAN7-1. Protoplasts were treated with an equimolar mixture of both plasmids and transformants selected for $\mathrm{HmB}$ resistance. $\mathrm{HmB}^{\mathrm{R}}$ transformants arose at a frequency of approximately 1 per $\mu \mathrm{g}$ pAN7-1 DNA used, somewhat lower than previous reports of transformation frequency for this species (Farman \& Oliver, 1988). Five potential cotransformant colonies were inoculated by hyphal transfer on to PDA plates, PDA plates containing $150 \mu \mathrm{g} \mathrm{HmB} \mathrm{ml}^{-1}$ and PDA plates containing $2.5 \mu \mathrm{g} \mathrm{MBC} \mathrm{ml}^{-1}$ (Fig. 4). The recipient strain $345 \mathrm{~A} 4$ and a number of $\mathrm{HmB}^{\mathrm{R}}$ transformants arising from treatment with pAN7-1 alone were also inoculated on these plates. All but the recipient grew on the $\mathrm{HmB}$ plates. The recipient, all the transformants from the pAN7-1 transformation and one of the transformants from the pAN7-1/pTUBA4 transformation were completely inhibited by MBC. However, 
the other four of the latter transformants grew in the presence of $\mathrm{MBC}$, indicating that they had been cotransformed with pAN7-1 and pTUBA4 and showing that high-frequency cotransformation takes place in $L$. maculans as well as in $S$. nodorum and other fungal species (Kelly \& Hynes, 1985; Punt et al., 1987; Wernars et al., 1987; Cooley et al., 1990).

These cotransformation experiments in $L$. maculans show that the Septoria tubA $\mathrm{A}^{\mathrm{R}}$ gene confers $\mathrm{MBC}$ resistance in a heterologous species and suggest that pTUBA4 could be used to transform other Ascomycete and Deuteromycete species by direct selection. In addition to the cotransformation with pTUBA4 reported here, $L$. maculans has also been transformed with this vector by selection for MBC resistance (M. L. Farman, personal communication). The $N$. crassa and $A$. niger tubulin genes have also been shown to confer MBC resistance following transformation into several Ascomycetes and Deuteromycetes (Dickman, 1988; Henson et al., 1988; Rambosek \& Leach, 1987; Cooley et al., 1990 ; Bernier et al., 1989), suggesting that $\beta$-tubulin genes are sufficiently conserved within and between these taxa for their products to copolymerize and function in heterologous backgrounds.

\section{$S$. nodorum has a single $\beta$-tubulin gene}

Digested genomic DNA from $S$. nodorum BS171 was probed in Southern hybridizations at low stringency [at $42{ }^{\circ} \mathrm{C}$ in $25 \%(\mathrm{v} / \mathrm{v})$ formamide, $5 \times \mathrm{SSC}, 1 \times$ Denhardt's solution, $100 \mu \mathrm{g}$ salmon sperm DNA ml${ }^{-1}, 10 \%$ $(\mathrm{w} / \mathrm{v})$ dextran sulphate, $20 \mathrm{~mm}$-orthophosphate, $\mathrm{pH} 6 \cdot 5$ ] with the $2.0 \mathrm{~kb}$ PstI fragment of pTUBA4 which shows homology with benA and which spans the BamHI site of ${ }_{t u b \mathrm{~A}^{\mathrm{R}}}$ (Fig. 1). With either PstI- or HindIII-digested DNA, a single positive hybridization signal was observed corresponding to fragments of 2.0 and $5.8 \mathrm{~kb}$, respectively (Fig. 5). These are the sizes of fragments predicted by the restriction map of the Septoria insert of pTUBA4, suggesting that $S$. nodorum has a single $\beta$ tubulin gene, or at least only one gene with sufficient homology to hybridize to a tubA-specific sequence. $S$. nodorum is like $N$. crassa in this respect (Orbach et al., 1986) and unlike $A$. nidulans, which possesses two $\beta$ tubulin genes (May et al., 1987). These data also demonstrate that the $\beta$-tubulin gene was not rearranged during its cloning.

\section{Conclusion}

Our aim of developing a homologous transformation system for $S$. nodorum based on selection for an MBCresistant $\beta$-tubulin gene was realized. However, the transformation frequency obtained using the $t u b \mathrm{~A}^{\mathrm{R}}$ gene

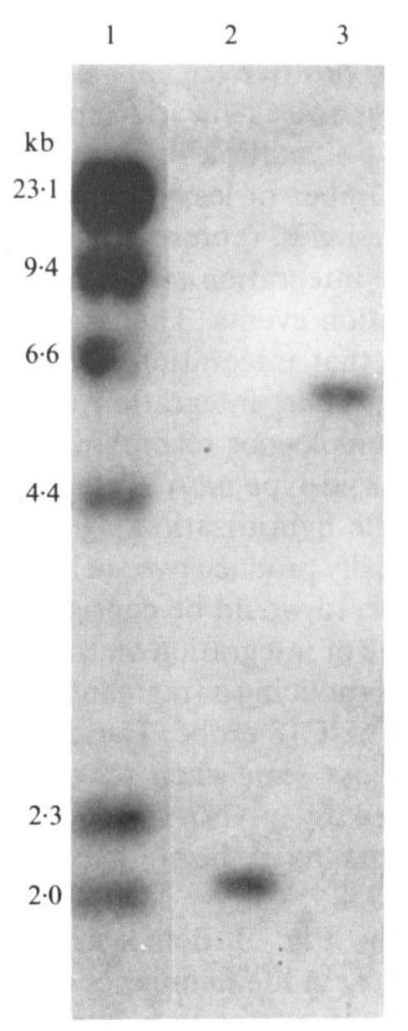

Fig. 5. Southern hybridization analysis of the $S$. nodorum $\beta$-tubulin gene. DNA $(0.4 \mu \mathrm{g})$ from strain BS171 was digested with PstI (lane 2) and HindIII (lane 3) and probed with the ${ }^{32} \mathrm{P}$-labelled $2.0 \mathrm{~kb}$ Pst $\mathrm{I}$ fragment of pTUBA4. Lane 1 contained $\lambda$-HindIII standards.

as a homologous dominant selectable marker was disappointing as it did not show any improvement on the frequency obtained using the heterologous hygromycin resistance encoded by pAN7-1 (Cooley et al., 1988). Panaccione et al. (1988) reported that comparable frequencies were obtained when transforming Colletotrichum graminicola with homologous and heterologous benomyl-resistance genes. These results suggest that with a highly conserved gene like $\beta$-tubulin homology is not an important factor determining transformation frequency within Ascomycetes and Deuteromycetes. This is consistent with the high frequency of nonhomologous integration observed even with vectors carrying extensive regions of homology (Fincham, 1989). Despite this failure to improve the efficiency of transformation of $S$. nodorum, the MBC-resistance gene cloned may be generally useful as a dominant selectable marker for transformation of related phytopathogenic fungi, particularly those naturally resistant to hygromycin.

We are grateful to Dr. K. J. Doughty of the Institute of Arable Crops Research, Rothamsted Experimental Station, for providing the strain of L. maculans. We also thank Mr Robert Shaw for his assistance in the 
mutagenesis work, Dr Christopher Franklin for his constructive advice and the preparation room staff from both Birmingham and TNO for their general support. This work was funded by grants from the Agricultural and Food Research Council (PG6/140), the Gatsby Charitable Foundation and the European Molecular Biology Organisation (ASTF 5399). It was carried out under MAFF licence numbers PHF 78A/109(97), PHF 78A/68(17), PHF 78A/111(28) and PHF $78 \mathrm{~A} / 73(27)$.

\section{References}

Bernier, L., Cooper, R. M., Charnley, A. K. \& Clarkson, J. M. (1989). Transformation of the entomopathogenic fungus Metarhizium anisophilae to benomyl resistance. FEMS Microbiology Letters 60, 261-266.

BORCK, K. \& BRAYMER, H. D. (1974). The genetic analysis of resistance to benomyl in Neurospora crassa. Journal of General Microbiology 85 , $51-56$.

Cooley, R. N., Shaw, R. K., Franklin, F. C. H. \& Caten, C. E. (1988). Transformation of the phytopathogenic fungus Septoria nodorum to hygromycin B resistance. Current Genetics 13, 383-389.

Cooley, R. N., Franklin, F. C. H. \& Caten, C. E. (1990). Cotransformation in the phytopathogenic fungus Septoria nodorum. Mycological Research 94, 145-151.

DiCKMAN, M. B. (1988). Whole cell transformation of the alfalfa fungal pathogen Colletotrichum trifolii. Current Genetics 14, 241-246.

Farman, M. L. \& Oliver, R. P. (1988). The transformation of protoplasts of Leptosphaeria maculans to hygromycin B resistance. Current Genetics 13, 327-330.

Feinberg, A. P. \& Vogelstein, B. (1983). A technique for labelling restriction endonuclease fragments to high specific activity. Analytical Biochemistry 132, 6-13.

Feinberg, A. P. \& Vogelstein, B. (1984). Addendum. Analytical Biochemistry 137, 266-267.

FinchaM, J. R. S. (1989). Transformation in fungi. Microbiological Reviews 53, 148-170.

Henson, J. M., Blake, N. K. \& Pilgeram, A. L. (1988). Transformation of Gaeumannomyces graminis to benomyl resistance. Current Genetics 14, 113-117.

Hiraoka, Y., Toda, T. \& Yanagida, M. (1984). The NDA3 gene of fission yeast encodes $\beta$-tubulin: a cold sensitive nda 3 mutation reversibly blocks spindle formation and chromosome movement in mitosis. Cell 39, 349-358.

Horsten, J. \& FehrmanN, H. (1980). Fungicide resistance of Septoria nodorum and Pseudocercosporella herpotrichoides. Zeitschrift für Pflanzenkrankheiten und Pflanzenschutz 87, 439-453.

Kelly, J. M. \& HYNES, M. J. (1985). Transformation of Aspergillus niger by the amd $\mathrm{S}$ gene of Aspergillus nidulans. European Molecular Biology Organisation Journal 4, 475-479.

King, J. E., CoOK, R. J. \& Melville, S. C. (1983). A review of Septoria diseases of wheat and barley. Annals of Applied Biology 103, 345-373.

LEONG, S. \& HoldEN, D. W. (1989). Molecular genetic approaches to the study of fungal pathogenesis. Annual Review of Phytopathology 27, 463-481.
Maniatis, T., Fritsch, E. F. \& Sambrook, J. (1982). Molecular Cloning, a Laboratory Manual. Cold Spring Harbor, NY: Cold Spring Harbor Laboratory.

May, G. S., Gambino, J., Weatherbee, J. A. \& MorRis, N. R. (1985). Identification and functional analysis of $\beta$-tubulin genes by site specific integrative transformation in Aspergillus nidulans. Journal of Cell Biology 101, 712-717.

May, G. S., Tsang, M. L.-S., SMith, H., Fidel, S. \& Morris, N. R. (1987). Aspergillus nidulans $\beta$-tubulin genes are unusually divergent. Gene 55, 231-243.

Newton, A. C. \& Caten, C. E. (1988). Auxotrophic mutants of Septoria nodorum isolated by direct screening and by selection for resistance to chlorate. Transactions of the British Mycological Society 90, 199-207.

Orbach, M. J., Porro, E. B. \& Yanofsky, C. (1986). Cloning and characterization of the gene for $\beta$-tubulin from a benomyl-resistant mutant of Neurospora crassa and its use as a dominant selectable marker. Molecular and Cellular Biology 6, 2452-2461.

Osbourn, A. E., Scott, P. R. \& CATEN, C. E. (1986). The effects of host passaging on the adaptation of Septoria nodorum to wheat and barley. Plant Pathology 35, 135-145.

Panaccione, D. G., McKiernan, M. \& Hanau, R. M. (1988). Colletotrichum graminicola transformed with homologous and heterologous benomyl-resistance genes retains expected pathogenicity to corn. Molecular Plant-Microbe Interactions 1, 113-120.

Punt, P. J., Oliver, R. P., Dingemanse, M. A., Pouwels, P. H. \& van DEN HONDEL, C. A. M. J. J. (1987). Transformation of Aspergillus based on the hygromycin B resistance marker from Escherichia coli. Gene 56, 117-124.

RAMBoseK, J. \& LEACH, J. (1987). Recombinant DNA in filamentous fungi: progress and prospects. CRC Critical Reviews in Biotechnology 6, 357-393.

SHEIR-Neiss, G., LAI, M. H. \& MoRRIS, N. R. (1978). Identification of a gene for $\beta$-tubulin in Aspergillus nidulans. Cell 15, 639-647.

ThOMAS, J. F., NeFF, N. F. \& Botstern, D. (1985). Isolation and characterization of mutants in the $\beta$-tubulin gene of Saccharomyces cerevisiae. Genetics 112, 715-734.

VAN TUYL, J. M. (1977). Genetics of fungal resistance to systemic fungicides. PhD thesis, Wageningen Agricultural University, The Netherlands.

Vollmer, S. J. \& Yanofsky, C. (1986). Efficient cloning of genes of Neurospora crassa. Proceedings of the National Academy of Sciences of the United States of America 83, 4869-4873.

WARING, R. B., MAY, G. S. \& MoRRIS, N. R. (1989). Characterization of an inducible expression system in Aspergillus nidulans using alcA and tubulin coding genes. Gene 79, 119-130.

Wernars, K., Goosen, T., Wennekes, B. J. J., Swart, J., van Den HoNDEL, C. A. M. J. J. \& VAN DEN BRoEK, H. W. J. (1987). Cotransformation of Aspergillus nidulans: a tool for replacing fungal genes. Molecular and General Genetics 209, 71-77.

Yoder, O. C., Weltring, K., Turgeon, B. C., Garber, R. C. \& VAN ETTEN, H. D. (1986). Technology for molecular cloning of fungal virulence genes. In Biology and Molecular Biology of Plant-Pathogen Interactions (NATO ASI Series H, vol. 1), pp. 371-384. Edited by J. A. Bailey. Berlin: Springer-Verlag. 